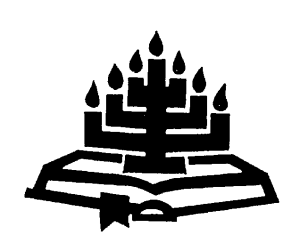

\title{
Jesus se gesaghebbende prediking as onderbou van sy opdrag om te gaan doop
}

\author{
B.J. de Klerk \\ Eenheid vir Reformatoriese Teologie \\ Potchefstroomkampus \\ Noordwes-Universiteit \\ POTCHEFSTROOM \\ E-pos: ben.deklerk@nwu.ac.za
}

\section{Abstract \\ The authority of Jesus' preaching and the baptism}

The question investigated in this article is what the relation is between the authority of the preaching of Jesus and the baptism that He instituted. The purpose is to reach practicetheoretical deductions regarding the effect what the authority of Jesus' preaching might have on the baptism. Firstly, the focus is on the meaning of the authority of the preaching of Jesus, and consequently on the relation between the authority of Jesus' preaching and the baptism based on Matthew 28:18-20. Lastly, the emphasis is on determining some practice-theoretical deductions of this for the baptism. Jesus' preaching is founded in his unity with his Father, his mandate as Messenger and his self-testimony. Therefore, his preaching has absolute authority. His preaching works that which it proclaims, and demands faith from the listener. The fact that Jesus has sovereign power, gives Him the right to give the command to baptise. Baptism serves to reveal Christ's divine glory. Through baptism Jesus sets his authority over the life of the baptised and the covenant parents, and as a result He can also demand unconditional obedience from them. His authority is enacted through preaching, because Jesus continues his authority in his preaching, even today. 


\section{Opsomming}

\section{Jesus se gesaghebbende prediking as onderbou van sy opdrag om te gaan doop}

Die vraag wat in hierdie artikel ondersoek word, is die verband tussen die gesag van Jesus se prediking en die doop wat deur Hom ingestel is. Die doel is om tot praktyk-teoretiese gevolgtrekkings te kom oor die uitwerking wat die gesag van Jesus se prediking op die doop mag hê. Eers word op die betekenis van die gesag van Jesus se prediking gefokus en vervolgens op die verband tussen die gesag van Jesus se prediking en die doop aan die hand van Matteus 28:18-20. Laastens word enkele praktyk-teoretiese afleidings daaruit vasstel vir die doop. Omdat Jesus se prediking in sy eenheid met sy Vader, sy volmag as Gestuurde en sy selfgetuienis begrond word, het sy prediking volstrekte gesag. Sy prediking bewerk wat dit verkondig en eis van die hoorder geloof. Die feit dat Jesus alle mag het, gee aan Hom die reg om die opdrag tot doop te gee. Die doop dien om Jesus se koningsheerlikheid te openbaar. Deur die doop laat Jesus sy seggenskap oor die lewe van die gedoopte en die doopouers geld en kan Hy ook van hulle onvoorwaardelike gehoorsaamheid eis. Die gesag word deur die prediking uitgeoefen, omdat Jesus sy gesag tot vandag toe deur die prediking voortsit.

\section{Inleiding}

Twee deurslaggewende redes het tot die kombinasie van die gesag van Jesus se prediking en die doop in hierdie artikel aanleiding gegee. Die outeur van hierdie artikel het sy verhandeling oor die gesag van Jesus se prediking (De Klerk, 1975) onder die inspirerende leiding van Tjaart van der Walt voltooi. Laasgenoemde het prinsipiële lyne in 'n deurslaggewende rapport oor die doop van aangenome kinders vasgelê (GKSA, 1970:131-137). Die volgende vraag het hierdeur ontstaan: Watter verband is daar tussen die gesag van die prediking van Jesus en die doop wat deur Hom ingestel is? Die doel is om tot praktyk-teoretiese gevolgtrekkings te kom oor die uitwerking wat die gesag van Jesus se prediking op die doop mag hê. 'n Eksegeties-openbarings-historiese metode word gevolg (vgl. De Klerk \& Janse van Rensburg, 2005:77-82). In hierdie artikel word eerstens gefokus op die betekenis van die gesag van die prediking van Jesus aangaande die fundering, aard, uitwerking, doel en funksionering daarvan. Vervolgens val die klem op die verband tussen die gesag van Jesus se prediking en die doop aan die hand van Matteus 28:18-20. Laastens word op die vasstelling 
van enkele praktyk-teoretiese afleidings daaruit vir die doop gefokus.

Die artikel word beperk tot die verhouding tussen die prediking van Jesus en die doopsbevel in Matteus 28 Die bespreking oor die aard van die doop deur die dissipels, asook oor hulle prediking voor die groot opdrag in die Evangelies, word egter uitgesluit. Die artikel handel oor Jesus se eie prediking en nie oor die boodskap wat deur sy volgelinge oorgedra is nie.

\section{Die gesag van die prediking van Jesus}

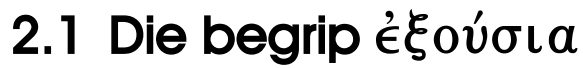

Die eenparige konklusie waartoe die vier evangeliste oor die gesag van Jesus kom, kan afgelei word uit die woorde in Matteus 7:29: “... Hy het hulle geleer soos 'n man met gesag ...". Wat die gesag beteken en waaruit dit bestaan, is die inhoud van die prediking van Jesus. Daarom is die kardinale vrae: Waaruit vloei die gesag van Jesus se prediking voort en wat is die aard daarvan? Hoe sien Jesus sy gesag? Gee Hy 'n aanduiding vanwaar dit kom en hoe Hy dit gebruik?

In die Nuwe Testament is dit duidelik dat die Vader nie volmag van 'n "hoër instansie" ontvang nie: Hy het dit in Homself (Hand. 1:7). Die ' $\xi^{\prime} \xi_{0}$ vı $\alpha$ van God word in die Nuwe Testament geopenbaar in dit wat Jesus as die Messias tydens sy aardse lewe gedoen het, in die hede doen en by sy wederkoms sal doen. Ook Jesus se $\mathfrak{\epsilon}^{\prime} \xi_{\text {ov́ }} \sigma \mathrm{\iota} \alpha$ is universeel. Dit word veral in sy verhouding tot die skare (Matt. 11:27; Joh. 1:12) ontplooi asook in sy mag om te oordeel

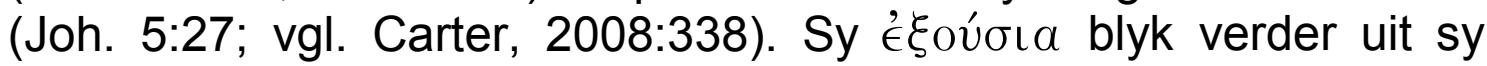
woord (Matt. 7:29), genesings en wonders, sy vergewing van sondes (Mark. 2:10), die uitdryf van onreine geeste (Mark. 1:27) en die beskikking oor sy eie lewe (Joh. 10:18; Bauckham \& Mosser, 2008:224).

Die begrip $\epsilon^{\prime} \xi_{0}$ v́ $\sigma \iota a$ word in die Nuwe Testament dikwels in verskillende verbande gebruik. Daar is nie sprake van een spesifieke betekenis wat op alle plekke waar '́ $\xi_{\text {ov }} \sigma \iota \alpha$ voorkom, toegepas kan word nie. Die persoon of saak wat die $\epsilon^{\prime} \xi_{\text {ov́ }} \sigma \iota \alpha$ besit en die verband waarin dit in die betrokke perikoop voorkom, bepaal die besondere inhoud van die begrip op daardie spesifieke plek (Krentz, 2006:27). 
Louw en Nida (1996) onderskei agt semantiese velde vir mag

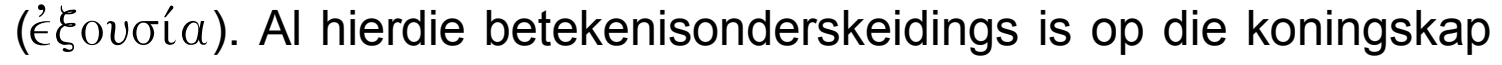
van Jesus van toepassing. Die betekenis wissel van 'n figuurlike uitbreiding van die woord troon (12.44), 'n staat van mag of beheer (37.13), 'n reg en vermoë om regterlik te kan oordeel (30.122; 37.35), jurisdiksie of 'n domein van gesag (37.36), en 'n simbool van gesag (37.37). Jesus tree dus hier na vore as die groot Koning van al die nasies, wie se heerlikheid oor die hele aarde verkondig moet word.

\subsection{Die fundering en aard van sy gesag}

Waarin rus die gesag van Jesus se prediking? Die gesagsvraag in Matteus 21:23-27 bied die belangrikse basiese beginsels van die fundering van Jesus se gesag. Dit gaan veral oor die roeping en opdrag van Jesus. Hy kies die plek (tempel, buitenste voorhof, want die gesprek moes in die openbaar plaasvind), en die tyd (net na sy koninklike intog in Jerusalem en sy gesaghebbende optrede deur die tempelreiniging). Die Sanhedriste vra hulle vraag na sorgvuldige raadpleging (Mark. 11:18). Hulle vra na Jesus se geloofsbriewe, na die geheim van sy Persoon en gesag (Van Bruggen, 1992:252). Die vraag is eintlik 'n dubbele vraag: "Met watter gesag doen $U$ hierdie dinge?" en "Wie het $U$ hierdie gesag gegee?" Dit gaan oor die aard

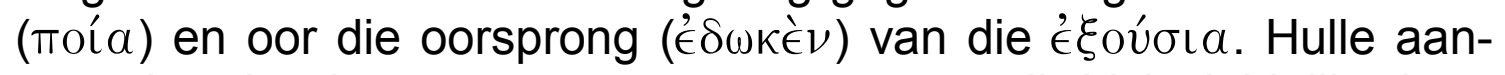
vaar dus dat Jesus met gesag optree, want dit blyk duidelik uit sy dade. Die direkte aanleiding tot die vraag is die tempelreiniging, hoewel die vraag ook op Jesus se prediking in die algemeen betrekking het (Blomberg, 1992:319).

Sy vraagstellers het gehoop dat Jesus Homself in die openbaar as Seun van God sou verklaar, want dan kon hulle Hom van godslastering beskuldig. Hulle vra Hom dus goddeloos en skaamteloos na iets wat vir hulle klinkklaar is. Om hierdie skynheiligheid bloot te lê en die vraag as strikvraag te ontbloot, antwoord Jesus nie direk nie, maar vra 'n teenvraag - 'n metode wat dikwels in die twisgesprekke van die Rabbyne gevolg is (Allison, 2004:356). Jesus plaas sy vraagstellers voor een van die mees brandende vrae in die destydse Israel: "Wat dink julle van Johannes die Doper?" (Keener, 1999:506.) Waarom sou Jesus nou juis na die doop van Johannes vra? Die $\beta a \pi \tau i ́ \sigma \mu \alpha$ van Johannes word hier nie slegs as teken van die afwassing van sonde bedoel nie, maar ook as aanduiding van Johannes se arbeid. Jesus wil dus 'n antwoord uitlok op die vraag of Johannes wesenlik en wettig 'n profeet van God, of 'n bedrieër was. 
Uit die optrede van die vraagstellers was dit vantevore reeds duidelik dat hulle nie veel van Johannes se doop gedink het nie. Sommige Sanhedriste wou hulle laat doop (Matt. 3:7), maar Johannes wou nie, omdat hulle nie bewyse van waaragtige bekering getoon het nie. Die grootste meerderheid het egter nie eers probeer om hulle te laat doop nie (Luk. 7:30; Blight, 2007:307). Aan die ander kant kon hulle hulle nie openlik teen Johannes uitspreek nie, want hulle was bang vir die skare. Jesus laat hulle besef dat Hy deur hulle sien. Hy sien nie alleen hulle ongeloof in dít wat Johannes begin het en $\mathrm{Hy}$ voortsit nie, maar Hy ontbloot ook hulle geveinsdheid deurdat hulle nie waag om Hom voor die skare te gryp nie. Die priesterhoofde en familiehoofde antwoord dus dat hulle nie weet nie - nie omdat hulle onkundig is nie, maar omdat hulle nie wil sê nie (Allison, 2004:357). Volgens die reël van Deuteronomium 13 en 18 kon die Joodse leiers egter afgelei het dat Jesus van die Vader kom.

Jesus laat hierdie mense nie sonder antwoord nie. Hy verwys hulle hier na hulle negatiewe antwoord wanneer Hy sê: "Dan sê Ek ook nie vir julle met watter gesag ek hierdie dinge doen nie." (Matt. 21:27.) Sy teenvraag in vers 25 is tegelyk ook 'n antwoord: Kom Jo-

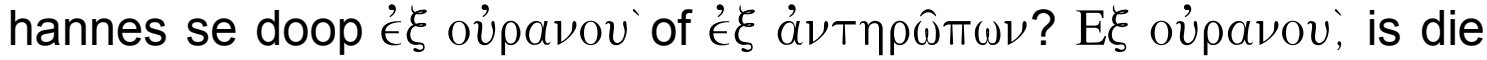
tipies Joodse omskrywing vir "van God" (Blomberg, 1992:320).

God is die bron van Jesus se gesag. Hy besit die gesag as Seun van God weens sy eenheid met die Vader. Van die eenheid met die Vader word egter nie in abstracto gepraat nie, maar die eenheid word geopenbaar in gelykheid in werke, woorde en lewe (Brodie, 1993:370). Die in-mekaar-wees berus op die eenheid van goddelike natuur. Jesus kan dus op die visio Dei aanspraak maak. Die Vader hou niks vir die Seun verborge nie. Die mededeling aangaande die Vader is eksklusief die voorreg van die Seun (Barrett, 1970:141). Jesus se woord is 'n woord wat van die Vader uitgaan en nie deur 'n mens gemaak is nie en juis daarom eis dit geloof. Die wesenseenheid van die Seun met die Vader is die eerste en beslissende grondslag vir die gesag van Jesus. Die gelykheid met die Vader word egter nooit in die evangelie van die opdrag en volmag van Jesus losgemaak nie. Enersyds is Hy en die Vader gelyk; andersyds is Hy die Gestuurde wat in gehoorsaamheid 'n taak het om te vervul (Edwards, 2004:158). As Seun is Hy aan die Vader gelyk; as Middelaar aan die Vader onderworpe. Die Vader gee aan die Middelaar

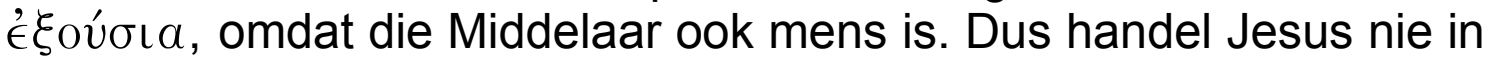
eie reg nie, maar in opdrag van sy Sender. Jesus is 'n Gevolmagtigde van sy Sender met 'n welomskrewe opdrag. Alles wat Hy spreek en doen, geld as woorde en dade van sy Sender en sy uit- 
sprake is so regsgeldig asof die Sender self die gesprek gevoer het. Daarby is Hy God se Sjaliach in besondere sin: niemand kan buite Hom in verhouding met God staan nie. Hy tree op "in die Naam van die Vader"; in opdrag van die Vader. Hy gebruik sy '́ $\xi_{0 u v} \sigma \iota \alpha$ volgens die wil van die Vader. God is Outeur van sy prediking (Joh. 17:8) en $\mathrm{Hy}$ is die Woordvoerder. Wie die woorde van Jesus ontvang, het waarlik met God te doen, omdat die Vader Hom gestuur het (Joh. 3:34).

Jesus tree dus op in die amp waarin die Vader Hom gestel het. Die doop van Jesus in die Jordaan openbaar die ewige uitverkiesing waardeur die Vader die Seun as die Messias en ook as die Sjaliach van die Vader aangewys het (McDonnell, 1995:216). Die neerdaling van die Heilige Gees ná die doop van Jesus is die amptelike salwing van die Messias deur die Vader (Mitchell, 2009:162). Dit is die goddelike toerusting van Jesus om sy opdrag uit te voer.

Uit sy wesenseenheid met die Vader vloei 'n verdere fondament waarop sy gesag staan, naamlik sy selfgetuienis. Die krag van sy getuienis rus op sy verhouding met die Vader. Aangesien Jesus self God is, weet Hy alles van sy verlede, hede en toekoms. Hy is bewus van sy goddelike oorsprong, roeping en opdrag. Wanneer iemand van Jesus moet getuig, kan niemand dit beter doen as Hyself nie. Sy eie getuienis is die volle waarheid. Wie dus Jesus se gesag bevraagteken, tas die almag en waaragtigheid van die drie-enige God aan, misken Christus se goddelike natuur en sy sending, en het 'n verwronge siening van die verhouding tussen die Vader en die Seun.

Jesus se prediking het daarom volstrekte gesag. Sy manier van leer en preek is meer as 'n saak van blote styl en spraak: aankondiging word by Hom afkondiging; verkondiging word die totstandbrenging van die blye genade wat Hy bekendmaak. Die Evangelies gebruik sekere woorde om die karakter van Jesus se prediking aan te dui. Die klem val hier by uitstek op die proklamerende, afkondigende aard daarvan. Jesus se prediking is die groot omskrywing van die nuwe gebeure, maar sy $\delta i ́ \delta a \chi \eta$ maak geheel en al 'n appèl op die hoorder. Hy is die getuie wat in opdrag getuienis aflê van dit wat Hy gesien en gehoor het. Die prediking van Jesus het deel aan die heilsgebeure self. Dit is die belangrikste aspek van die $\mu \alpha \rho \tau u ́ p ı \alpha-$

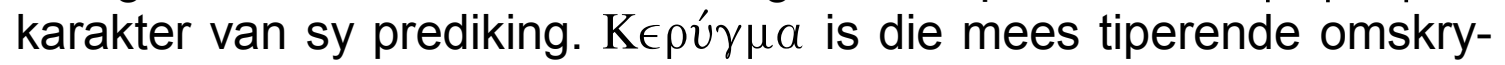
wing van die kwaliteit van die gesag van sy prediking. Dit beskryf die prediking as die aankondiging, die proklamasie van die nuwe en opsienbarende, naamlik die groot omkeer van die verlossende ingrype van God. Dit plaas die mens voor 'n radikale beslissing: Hy/sy word 
voor die eis van geloof en bekering gestel. Die $\kappa \in \rho u ́ \gamma \mu \alpha$ staan of val met die feitelikheid van historiese gebeure waarvan dit die proklamasie is. In die evangelieverkondiging word die koninkryk van die hemele ' $n$ teenwoordige werklikheid. Sy prediking is koninkrykstigtend.

Om hierdie besondere aard van Jesus se prediking nog meer te beklemtoon, plaas die evangeliste dit teenoor die prediking van sy tyd, naamlik dié van die Fariseërs en die Skrifgeleerdes. Wanneer die evangeliste sy prediking beskryf as "nie soos die Skrifgeleerdes nie", het dit nie op die preekstyl betrekking nie, maar op die wesenlike inhoud van die preek (Stott, 1978:214). Terwyl die Skrifgeleerdes ander outoriteite siteer om hulle leer te probeer handhaaf, grond Jesus sy leer op eie outoriteit: "Maar Ek sê vir julle ...". Hy eis daarvoor onvoorwaardelike gehoorsaamheid en verklaar dat die ewige saligheid daarvan afhang. Sy prediking het volstrekte en absolute gesag (Stott, 1978:215).

\subsection{Die uitwerking en doel van sy gesag}

Niemand kan teenoor Jesus se prediking neutraal staan nie, want sy woord maak 'n dringende appèl op elke hoorder. Herhaaldelik kom dit in sy prediking na vore dat die enigste, juisste reaksie daarop die

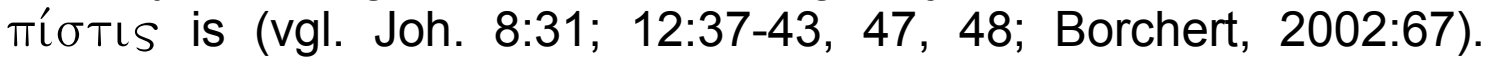
Jesus se prediking bring ook skeiding. Al was die doel van sy eerste koms nie om te oordeel nie, bring sy woord tog skeiding. Dieselfde woord wat nou verlossing aanbied ( $\lambda$ ó verkondiging saamvat; Joh. 12:48b) sal op die laaste dag die oordeel voltrek (vgl. Joh. 3:18). Die sprekende Jesus is dus tot veroordeling of tot vryspraak (Neyrey, 2007:83).

Die Fariseërs verwerp sy prediking, want hulle laat hulle deur 'n verkeerde beginsel beheers: "Hoe kan julle in My glo terwyl julle gesteld is op die eer wat julle van mekaar ontvang en nie die eer soek wat van die enigste God af kom nie?" (Joh. 5:44.) Die finale uitwerking van Jesus se prediking op die Fariseërs het Hom in 'n sekere sin aan die kruis gebring. Tog is dit hulleself wat, weens die hardheid van hulle harte, die ewige dood ingegaan het (Brodie, 1993:255). Die volk is aanvanklik verbaas oor die gesag waarmee Jesus preek (Matt. 7:28, 29). Die skare moes iets van die goddelike in Jesus se woord en werk ondervind het. Ongelukkig sit die verwondering meestal oor in ongeloof. Hulle het Hom tot op 'n sekere punt in groot getalle gevolg, maar dan kom die skeiding. Johannes teken dit in skerp taal (Joh. 6:66; vgl. ook Barrett, 1970:252): 


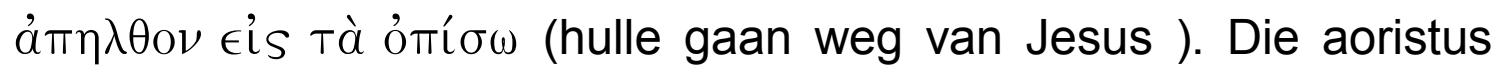
toon aan dat dit 'n eenmalige, finale daad was en dat hulle nooit weer na Hom teruggekeer het nie. Na die finale breuk kom daar nie herstel nie. Jesus se prediking openbaar dus die ongeloof van die volk en voltrek reeds die vonnis oor die volk tydens sy lewe op aarde. Die reaksie van die Twaalf is radikaal die teenoorgestelde. Hulle neem sy leer aan en erken die gesag van sy woorde, naamlik dat Jesus die Messias is wat deur God gestuur is. Petrus gee ook 'n rede vir sy antwoord (Joh. 6:68b): "U het die woorde wat ewige lewe gee." Jesus praat nie net van die ewige lewe nie, maar Hy deel dit uit deur sy woorde, omdat Hy dit as lewensbron besit (Moloney, 1998:229). Jesus se prediking eis geloof en die Twaalf erken dat die geloof in hulle harte is. Die uitwerking van Jesus se prediking het by die Twaalf ook sy doel bereik (net soos by die Fariseërs en die volk), want deur die band van die geloof, wat deur hulle belydenis bevestig is, is dit onmoontlik om Hom te verlaat.

Om 'n geheelbeeld van die gesag van die prediking van Jesus te verkry, moet ook die doel daarvan vasgestel word. Jesus handel hieroor in sy gebed vir die dissipels (Joh. 17). In hierdie gebed doen Jesus, as Sjaliach van God, as 't ware verslag van sy goddelike sending, naamlik die uitvoering van die Vader se opdrag. Die Vader het

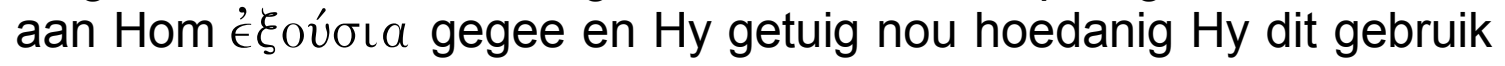
het. Hierdie is dus in werklikheid 'n gebed wat 'n verslag van Jesus se gesaghebbende werk bevat. Volgens Johannes 17:8 bestaan dit daaruit dat Jesus gepreek het (Moloney, 1998:464). Johannes 17 is egter meer as 'n verslag, want uit die gebed blyk onder andere ook wat Jesus se bedoeling met die gesag van sy prediking is.

Die gesag van sy prediking het as doel eerstens die verheerliking van sy Vader (Joh. 17:4). Jesus het die Vader verheerlik, omdat God se Naam aan die wêreld deur sy prediking en wonders bekend is. Jesus se openbaring van die Naam van God is sy verklaring of bekendstelling van die onsigbare God (Borchert, 2002:191). Om hierdie doel (om God te verheerlik) te kon bereik, moes Jesus met goddelike gesag preek. Die doel van sy prediking was ook dat die volk, en nie net Hyself nie, God moet verheerlik.

Jesus vra die Vader om Hom te verheerlik. Dit beteken dat Hy vir die loon op die werk wat Hy voltooi het, bid. Die loon bestaan daarin dat

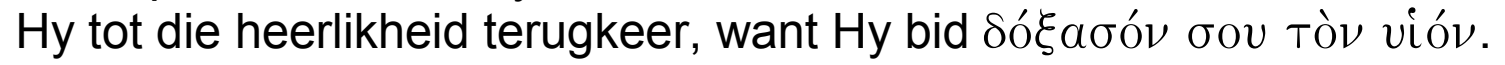
Jesus se preekgesag het dus ook ten doel dat Hy verheerlik word, sodat die Vader ook daardeur verheerlik kan word. Die verheerliking van die Seun, as doel van Jesus se gesag, word in die werk van die Heilige Gees voltrek. Johannes 16:14 se $\delta$ $\xi a ́ \sigma \in \iota$ dui aan dat dit die 
werk van die Heilige Gees is om die heerlikheid van Christus in die wêreld te laat skitter. Die koms van die Heilige Gees kan ook as 'n doel van die gesag van sy prediking genoem word, al is dit sekondêr (Moloney, 1998:442).

Die Seun het ook deur sy gesaghebbende prediking mag om aan die $\pi \alpha ́ \sigma \alpha \sigma a \rho \xi$ die Ewige Lewe te gee en daardeur die Vader te verheerlik. Die doel van die gesag van Jesus se prediking is dus ook om die Ewige Lewe te gee "aan almal wat U Hom gegee het" (Joh. 17:2). God het sy lewe in die Seun uitgestort en wie in die Seun glo,

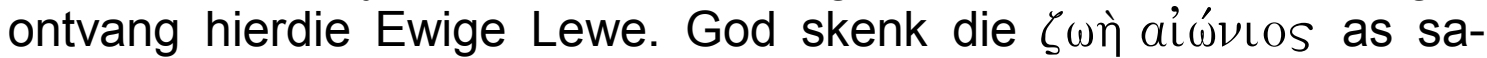
mevatting van die heil aan die mens (Borchert, 2002:191; Carter, 2008:210). Die ewigheidslewe bestaan uit kennis van die ware God en Jesus Christus. Om God te ken, is verheerliking van God.

\subsection{Die funksionering van sy gesag}

Jesus se woord is nie slegs 'n klank of 'n teken nie, maar is met mag gelaai. Dit beskik oor die saak, oor die heil wat dit aandui. Dit is nie slegs 'n woord nie, maar dit doen die wil van die Een wat spreek. Jesus het gekom om die heil en oordeel van die koninkryk te verkondig en deel van hierdie blye boodskap was om sondes te vergewe. Markus 2:1-12 verhaal die geskiedenis van die genesing van 'n verlamde man. In hierdie wonderwerk gaan die prediking vooraf: "Vriend, jou sondes word vergewe". Sonde is om teen God se wet in te gaan. Wie kan sondes vergewe, behalwe God? Alleen Hy teen wie die sonde bedryf word, kan dit vergewe (Gundry, 1993:112). Jesus ken Homself die reg en mag toe wat volgens die Ou Testament alleen aan God toekom (Eks. 34:6, e.v.; Jes. 43:25; 44:22; Van Seters, 1994:346). Die mens wat hierdie reg aan homself toeken, belaster God en die straf vir godslastering was steniging (Lev. 24:15, e.v.).

Hierdie reg van Jesus word deur die Skrifgeleerdes betwis en deur die wonder bewys Jesus aan hulle sy $\epsilon^{\prime} \xi o v ́ \sigma \iota \alpha$ om sondes te vergewe. Hy het mag om sondes te vergewe omdat Hy die Seun van die mens is en omdat Hy in 'n unieke verhouding tot sy Vader staan (Roskam, 2004:148). Die genesing is dus eintlik 'n bysaak om die mag van Jesus se woord te openbaar. Jesus lê dus klem op die verband tussen sondevergewing en genesing. Dit gaan in albei gevalle net om die spreek van 'n woord. "Wat is makliker?" (Mark. 2:9; Witherington, 2001:116). Sowel sondevergewing as genesing is God se werk. Om te sê: "Jou sondes is vergewe", kan nie geverifieer word nie, maar om te sê: "Staan op ..", is om jouself aan die toets van sukses of mislukking bloot te stel. Jesus is gereed om Hom aan 
die feitelike toets te onderwerp dat $\mathrm{Hy}$ nie sonder grond die uitspraak gemaak het dat die man se sondes vergewe is nie (Van Bruggen, 1992:69). Die feit dat Jesus óf kan sê "jou sondes is vergewe", óf "staan op, vat jou draagbaar ...", is 'n bewys van die krag van sy woord. Dit bly dieselfde magswoord wat sondevergewing preek en wonders doen (Witherington, 2001:117). Jesus se gesag funksioneer deur prediking, deur die woord. Die vergewing van sonde word nie slegs as boodskap gebring nie, maar word deur die woord van Jesus op die aarde voltrek. Dit is die nuwe en ongehoorde van sy prediking.

Sy prediking funksioneer ook deur die uitsending van sy dissipels. Die ámoбTè $\lambda \lambda \omega$ van die Twaalf is 'n belangrike funksie van die gesag van Jesus se prediking. Deur Jesus se prediking word die proses van uitsending voltrek, want die hoofmomente in die proses is roeping, toerusting en uitsending. Die roeping van die dissipels val saam met die begin van Jesus se messiaanse werk. Dit volg direk na sy salwing as Messias by sy doop en voordat Hy in die openbaar begin optree (Blomberg, 1992:81). Sy goddelike apostolaat begin Hy deur die roeping van sy latere apostels. Sy doel met hulle was dat hulle gedurige oor- en ooggetuies van sy woorde en dade moes wees, sodat hulle later as sy gevolmagtige verteenwoordigers kon optree en die blye boodskap kon gaan preek.

Nadat Matteus (Matt. 28:1-10) Jesus se opstanding beskryf het, haas hy hom om te vertel wat die opstanding vir Jesus en die dissipels inhou. Die omhulling wat die selfopenbaring van Jesus tot nou toe gekenmerk het, maak plek vir die openlike proklamasie dat Jesus beklee is met die onbegrensde mag van die Seun van die mens van Daniël 7 (Lucas, 2002:184). Die mag waarop Jesus hier aanspraak maak, is nie die skeppingsmag wat Hy reeds voor die skepping besit het nie, maar die $\mathcal{\epsilon}^{\prime} \xi_{0} v_{\sigma} \mathrm{l} \alpha$ wat Hy toe ontvang het (Matt.

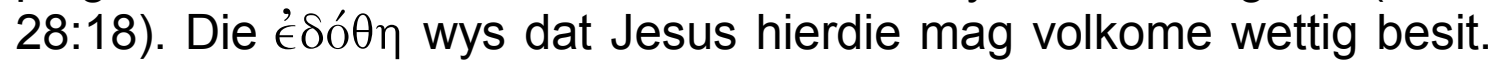
Hy was tot die dood toe gehoorsaam; Hy het sy taak volbring en nou ontvang Hy sy loon (vgl. Fil. 2:8; Heb. 5:5; 12:2). Dat God die Gewer is, word nie gesê nie, maar op grond van Jesus se prediking is dit veronderstel om bekend te wees. Die koms van die Seun van die mens (Dan. 7:13) het dus reeds plaasgevind wanneer Jesus hier aan sy dissipels verskyn. Die vervulling van Daniël 7:14 gee aan Je-

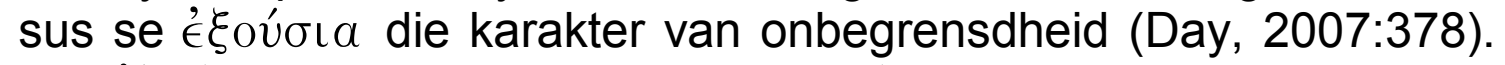
Die '́ $\xi_{0}$ ov́ voor die aangesig van God, gaan oor engele en strek hom ook oor die aarde uit, al is dit nie altyd sigbaar nie (Pennington, 2007:84). 
Die opstanding van Jesus het ook 'n besliste uitwerking op die dissipels. Voor die opstanding is hulle leerlinge (dissipels), maar na die opstanding volg die eintlike uitsending en word die dissipels Jesus se gevolmagtigde verteenwoordigers op aarde. Hulle word met gesag beklee, soos die sjaliach van die Jodedom. Hulle is ook aan Hom verantwoording verskuldig en moes hulle sjaliach-funksie met die volle oorgawe verrig. Hulle is gereed om die opdrag te ontvang, want 'n goddelike werking van die Here het aan hulle die vermoë gegee om die Skrifte te verstaan. Hulle weet nou dat wat met Hom gebeur het, volgens die Skrifte met Hom moes gebeur.

Die opdrag wat die dissipels hier ontvang, maak hulle apostels. Hulle word deur die woorde van Jesus blywend in die besondere amp gestel: "Soos die Vader My gestuur het, stuur Ek julle ook." (Joh. 20:21.) Christus gee om goeie redes dieselfde gesag wat Hy van die Vader ontvang het aan die apostels, want daardeur verklaar Hy dat hulle prediking in goddelike opdrag geskied. Jesus rus hulle veral toe met die Heilige Gees wat hulle vir hulle werk sou bekwaam. Wanneer Jesus voor sy hemelvaart hulle finaal uitstuur, blaas Hy op hulle en sê: "Ontvang die Heilige Gees" (Joh. 20:22). Dit dui profeties op die uitstorting van die Heilige Gees op Pinksterdag, want die dissipels kon nie met hulle opdrag begin voordat hulle met die krag van die Heilige Gees toegerus was nie. Ter wille van die voortsetting van sy gesaghebbende prediking is Christus en sy Gees altyd by sy apostels en sy kerk (Neyrey, 2007:327).

Matteus 28:19 en 20 verklaar hoe die $\mathfrak{\epsilon}^{\xi} \xi_{\text {ov́} \sigma \iota \alpha}$ funksioneer, naamlik dat dit deur die prediking werk. Die $\epsilon^{\prime} \xi o v ́ \sigma \iota \alpha$ wat eie aan die Seun van die mens is, stel Hy in diens van die prediking. Die apostolaat is deelneming aan die werk van Christus en sy handelinge word in die apostels se optrede voortgesit. Jesus het deur sy opstanding volle koninklike '́ $\xi_{\text {oov́} \sigma \iota \alpha}$ verkry en al vaar $\mathrm{Hy}$ op na die hemel, funksioneer sy volmagswerk steeds op aarde (Day, 2007:378). Hy sit sy werk voort deur menslike werktuie wat Hy tydens sy lewe op aarde geroep en voor sy hemelvaart toegerus en uitgestuur het met krag deur die Heilige Gees.

\section{Die gesag van Jesus se prediking en die doop volgens Matteus 28:18-20}

Volgens Ridderbos (1987:552) dien Matteus 28:18-20 as klimaks en samevatting vir die verstaan van die belangrikste temas van die boek. 
Careful study has shown, moreover, that in these verses are taken up some major themes running through the Gospel from the beginning. This truly is, then, a 'grand finale'. (Bosch, 1995:51.)

Die Evangelie volgens Matteus sluit met 'n proklamasie, bevel en belofte af. Dit is 'n besonder karakteristieke afsluiting van hierdie betrokke evangelis, want die hele Evangelie verkondig die koningsheerskappy en koningsheerlikheid van Jesus (Versteeg, 1983:34). In die geslagsregister, waarmee Matteus begin, word Jesus die Christus, die Seun van Dawid, die koning genoem. In Matteus 28:18 noem Jesus dat alle mag in die hemel en op aarde aan Hom gegee is. Die agtergrond van die tekening van Jesus se koningsheerlikheid is Daniël 7:13. In Daniël 7:13, 14 word van die oordrag van die wêreldheerskappy aan die Seun van die mens gepraat (Krentz, 2004: 27). Dit sluit die verhoging tot koningswaardigheid, die bekendmaking of proklamasie tot verhoging en die oordrag van die regeringsgesag aan die nuwe koning in (Floor, 1983:25). Christus het hierdie wêreldheerskappy as vrug van die werk wat Hy voltooi het, verkry. Hy is verhoog en daarna volg die opdrag tot proklamering daarvan in die sendingbevel en die belofte van die verhoogde Christus dat Hy in die vervulling van die opdrag Self tot aan die voleinding by sy kerk sal wees. Dat die bevel tot doop in die kader van Jesus se koningsheerlikheid staan, sê alreeds baie oor die aard van die doop. Die doop dien om Jesus se koningsheerlikheid te openbaar. Deur die doop laat Jesus, as Koning, sy regte oor die lewe van 'n gedoopte geld (Versteeg, 1983:35).

Jesus het die doop in die konteks van die groot opdrag ingestel (Doriani, 2003:35). Die geloof dat die instelling van die doop hoofsaaklik op Matteus 28:19 berus, word onder andere in die Heidelbergse Kategismus, vraag 71 bely. Om die plek van die doop in die konteks van die groot opdrag te kan bepaal, behoort die sintaktiese ontleding van Matteus 28:18-20 nagegaan te word (Pretorius, 2003: 146, 147 se sintaktiese ontleding word gevolg; vgl. ook Krentz, 2004:26). 


\subsection{Sintaktiese ontleding van Matteus 28:18-20}

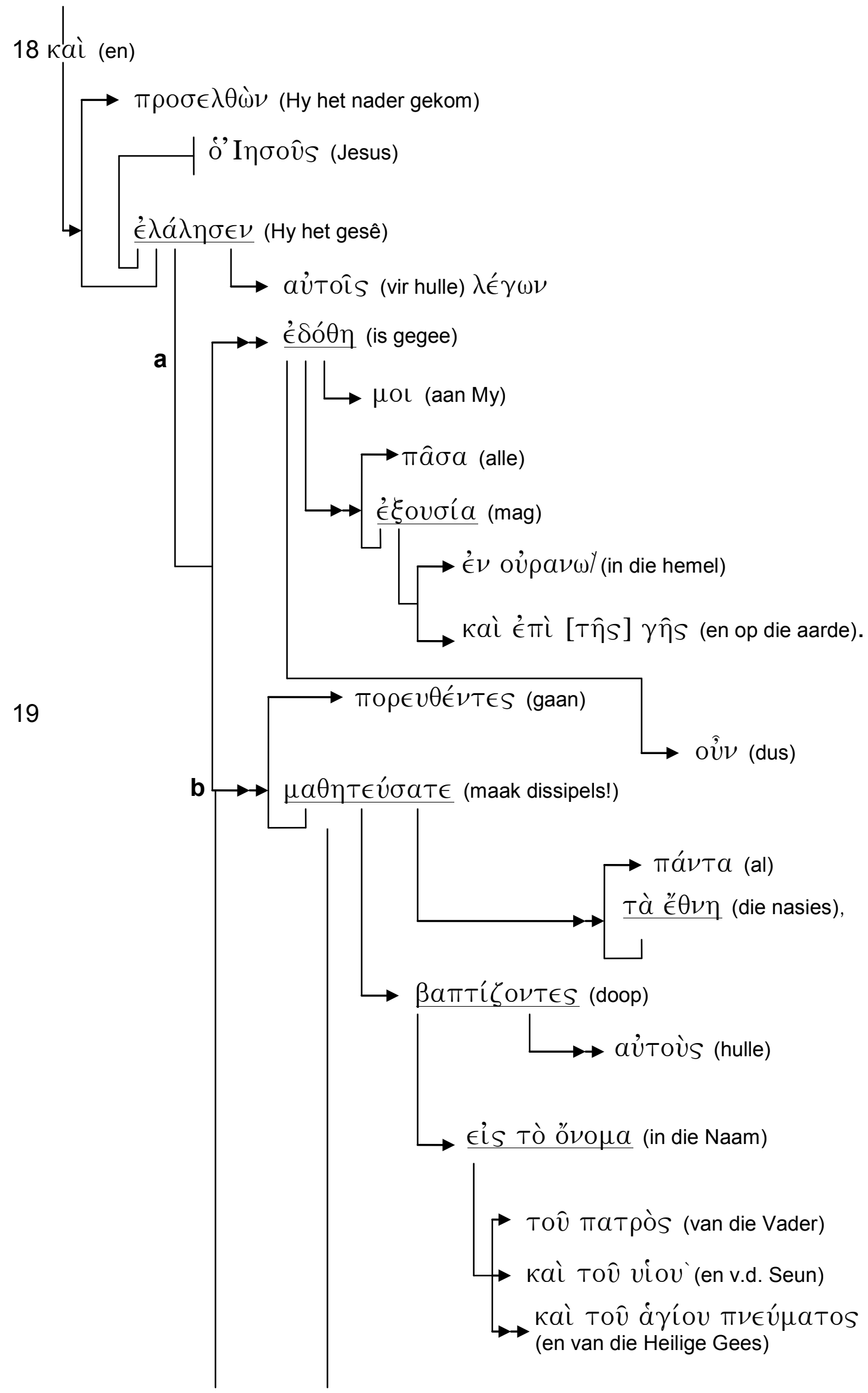


20

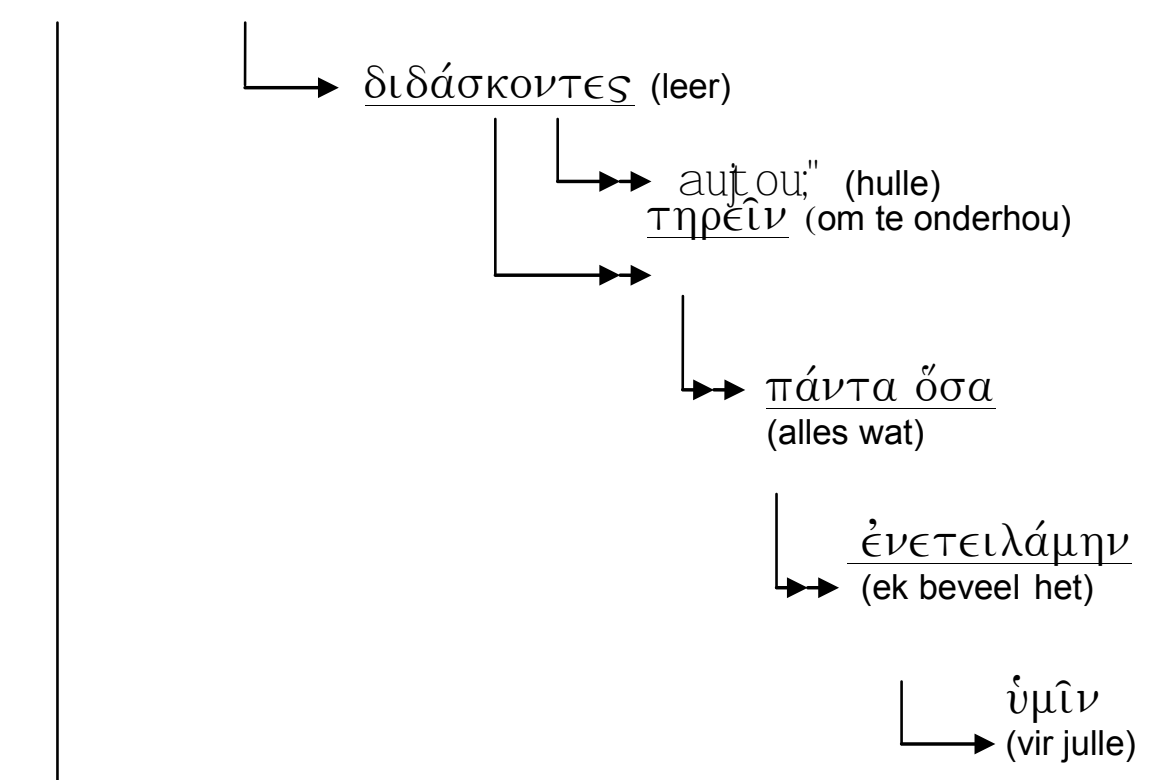

Kai íov (en kyk)

C
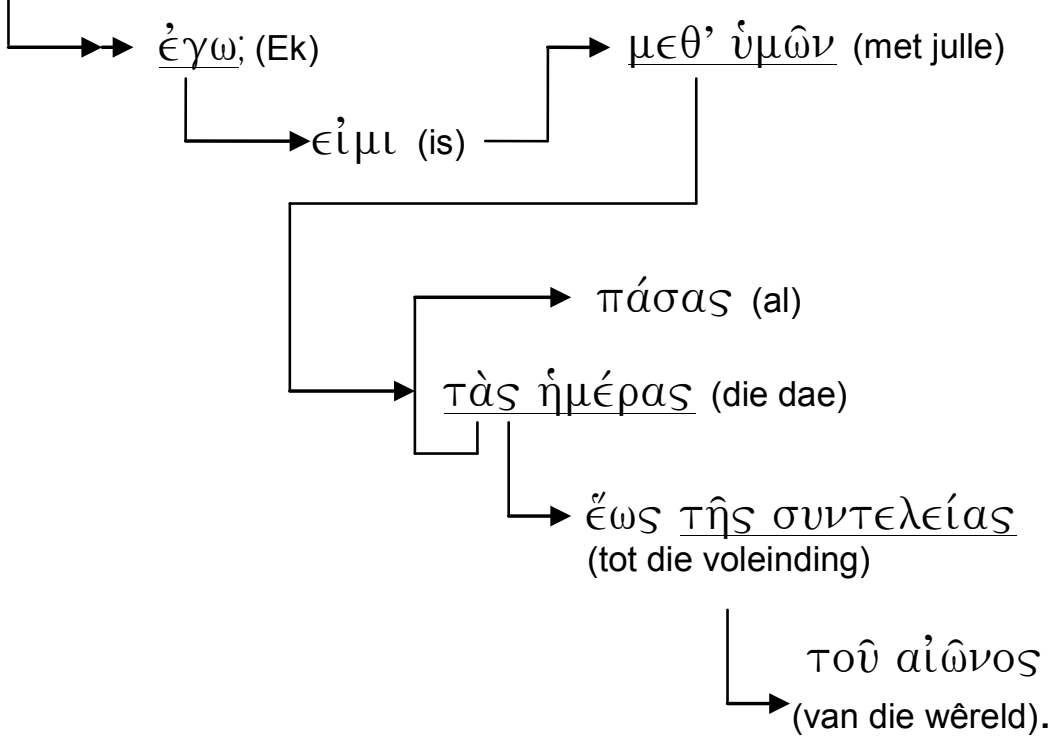


\subsection{Jesus het onbeperkte gesag}

Die opdrag gaan met unieke gesag gepaard. "It sounds like the enthronement of a king. This powerful king has an important message to His people." (Kvalbein, 1988:48.) "Is gegee" (aor. ind. pas. 3e pers. ekv. van $\delta i ́ \delta \omega \mu \iota)$, vestig die aandag op God die Vader as subjek (Pretorius, 2003:182). Die gebruik van die aoristus dui op tydloosheid (Robertson, 1998; Matt. 28:18). Die woorde wat volg na "is gegee" dui aan dat Jesus se mag eksklusief en omvattend is en verskaf die basis of indikatief vir sy omvattende en groot opdrag. Die sfeer van sy mag is onbeperk ("in die hemel en op die aarde") (Krentz, 2004:27). Na sy oorwinning aan die kruis, verkry Jesus die volledige koningskap. Voor die kruisiging was $\mathrm{Hy}$ in sy menslikheid

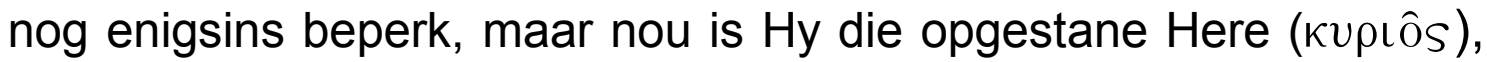
die Messias-Koning, wat binnekort in heerlikheid na die hemel sal opvaar (Hiebert, 1992:344).

He spoke as one already in heaven with a world-wide outlook and with the resources of heaven at his command. His authority or power in his earthly life had been great $(7: 29 ; 11: 27 ; 21: 23 f)$. Now it is boundless and includes earth and heaven. (Robertson, 1998.)

Omdat Jesus alle mag in die hemel en op aarde ontvang het, is dit sy reg om 'n opdrag so wyd soos die lewe self te gee (Doriani, 2003:34).

\subsection{Jesus se groot opdrag: "Maak dissipels van al die nasies"}

Hoe daar van alle volke dissipels gemaak kan word, word deur die

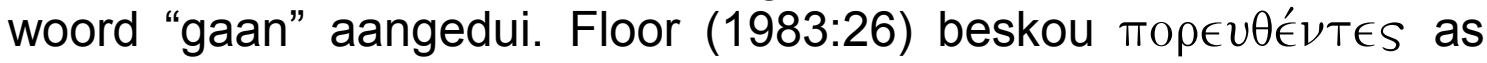
een van die drie maniere waarop dissipels gemaak moet word. Hy stel die opdrag en uitbreidings soos volg voor:

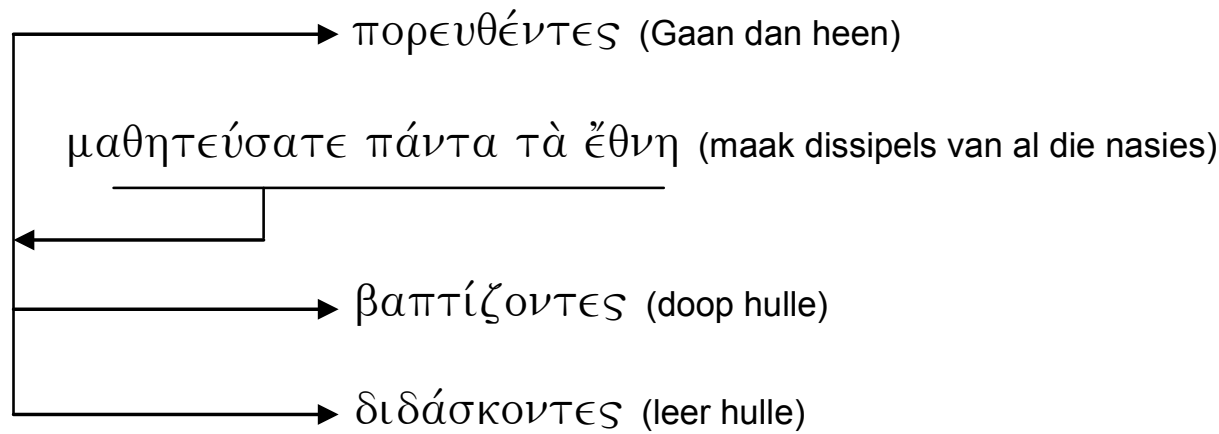


Die "gaan" dui primêr op die oorskreiding van die grense van Israel. Omdat die oproep tot verlossing nie langer tot Israel beperk is nie, is die konsekwensie dat die "gaan" gesien en beleef word (Krentz, 2006:29). Die feit dat die dissipels moes "gaan", word in Handelinge beskryf deurdat die dissipels in die destydse wêreld moes ingaan om die evangelie te verkondig (Doriani, 2003:35).

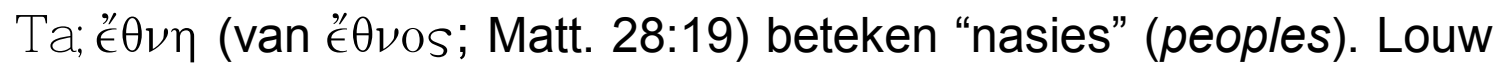
en Nida (1996:11.55) gee die volgende beskrywing: "the largest unit into which the people of the world are divided on the basis of their constituting a socio-political community - 'nation, people'". Keener (1999:719) stel: '“All nations' probably signifies 'all peoples' rather than the modern concept of 'national states'." Die aanduiding "na al die nasies" is 'n verwysing na Genesis 12:2 e.v. waar genoem word dat al die geslagte van die aarde in Abraham geseën sal word. Matteus noem Jesus juis die seun van Abraham (Matt. 1:1; 3:6-14; Voorberg, 2007:320).

Die inhoud van die maak tot dissipels word deur die werkwoordvorms aangegee wat oor die doop en die leer om te onderhou gaan (Beasley-Murray, 1999:474).

In cases such as Matt. 28:19, where participles follow one another without $\mathrm{k} \alpha \mathrm{l}$ or any other conjuction binding them to the main verb, they must be viewed as dependent on one another or depending in different ways to the main verb. (Doriani, 2003:37.)

Die "doop" en die "leer onderhou" bepaal die twee kante van dissipelskap: die doop vorm die goddelike kant en die leer onderhou wys op die menslike kant. Die twee kante kan nie van mekaar losgemaak word nie en veronderstel mekaar voortdurend. In die doop stel God die mens onder sy seggenskap op grond van die werk wat Jesus volbring het. Die leer om alles te onderhou wat Jesus beveel het, is om onder God se gesag te bly (Wilson, 2003:299). Geeneen van die twee kante kan gemis word nie, want in die eenheid daarvan realiseer die maak tot dissipels.

Aan een doop waarop niet volg het onderhouden van al wat Jezus geboden heeft kan niet op een automatische of magische wijze een betekenis in zichzelf toegekend worden. Andersyds staat ook het echte onderhouden van al wat Jezus geboden heeft niet op zichzelf. Het is gebaseerd op Gods gave in de doop. (Versteeg, 1983:39.) 
Die "doop hulle" wys op die indikatief en die "leer hulle" op die imperatief. Die imperatief van 'n lewe volgens die gebooie van Jesus, is nie 'n voorwaarde vir die indikatief van die doop nie. Die indikatief van die doop is wel gerig op 'n lewe van bekering en vernuwing volgens die gebooie van Christus. Daarsonder kom die doop nie tot sy doel en reg nie (Floor, 1983:27).

\section{4 "Doop hulle ..."}

Die woord in die Nuwe Testament vir doop is $\beta a \pi \tau i ́ \zeta \in \mathrm{L} \nu$ wat ont-

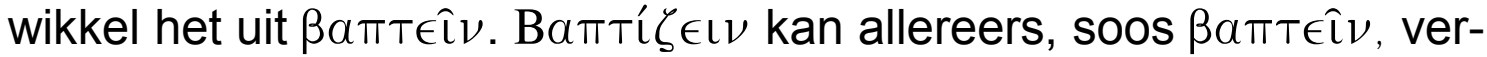
taal word met "indompel" of "onderdompel". Louw en Nida (1996:

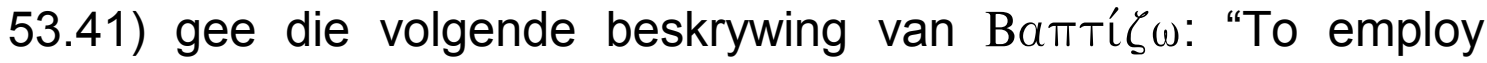
water in a religious ceremony designed to symbolize purification and initiation on the basis of repentance." Bamri $\zeta_{\omega}$ het in die Nuwe Testament hoofsaaklik 'n godsdienstige betekenis deurdat dit die verhouding met God raak (Waddell, 2009:88). In agtien van die 21 kere wat $\beta a \pi \tau i \zeta \zeta \in \nu$ byvoorbeeld in Handelinge en in die NuweTestamentiese briewe gebruik word, dui dit hoofsaaklik op die doop wat Jesus net voor sy hemelvaart as opdrag gee (Krentz, 2006:34; vgl. Hiebert, 1992:343).

\section{5 "Doop in die Naam van ..."}

In teenstelling met die doop van Johannes en van die dissipels wat aan die begin van Jesus se optrede bedien is, is die doop wat Jesus instel, 'n doop in Christus (Campbell, 1996:193). Die doop van Jesus deur Johannes sowel as die doop wat deur Johannes en sy dissipels bedien is, was geen koninkryksdoop nie. Die doop van Johannes en die dissipels word onderbou met die koms van die koninkryk. "Jesus' baptism did not prepare for the new age; it inaugurated it when linked with the preaching of Jesus' death and resurrection." (Doriani, 2003:39.) Die spesifieke van die doop in die Nuwe Testament is dat dit bedien word "in die Naam van Jesus" (vgl. Hand. 8:16). 'n Uitbreiding hiervan is in Matteus 28:19 waar die opdrag van Jesus is om "in die Naam van die Vader, en die Seun en die Heilige Gees" te doop. Die agtergrond waarteen die uitdrukking "doop in die naam van" verstaan moet word, kom uit die Ou Testament (Versteeg, 1983:13). In die besonder moet gedink word aan die seggenskap wat iemand kon uitoefen wanneer sy naam oor iemand anders of oor iets uitgeroep is (vgl. 2 Sam. 12:28). In Jesaja 63:19 is daar in die klag 'n duidelike parallel tussen die heers van God en die uitroep van die Naam van God. God heers oor hulle oor wie sy Naam uitgeroep is (Goldingay, 2001:360). Wanneer iemand in die Naam van 
Jesus gedoop word, laat Jesus deur die doop sy seggenskap oor die lewe van daardie persoon geld. Om gedoop te wees in die Naam van Jesus beteken dus "staan onder seggenskap van Jesus". Net so geld dit dat iemand wat in die Naam van die drie-enige God gedoop is, onder die seggenskap van daardie God staan.

Die gebruik van die voorsetsel $\epsilon$ is vestig die aandag daarop dat die Nuwe Testament nie op doop mét of ín water fokus nie, maar dit gaan altyd oor doop in of tot 'n persoon (Pretorius, 2003:166). In die woorde van Ridderbos (1987:554):

... the words baptize 'in (literally 'into') the name of the Father Son and the Holy Spirit' mean that the subject of baptism is brought into fellowship with and under authority of Him in whose name he is baptized.

Die woord naam (ovora) word meestal in die Bybel figuurlik gebruik om die persoon of wese self aan te dui (Louw \& Nida, 1996:9.19). In Matteus 28:19 word die dopeling dus aan die wese van die drieenige God en sy mag verbind. Ovora in Matteus 28:19 het die dieper betekenis van mag, heerlikheid, majesteit en luister, want Jesus het na sy verhoging 'n Naam bo alle name ontvang (Fil. 2:9). Wanneer iemand in die naam van 'n persoon gedoop word, word hy onder daardie persoon se mag en heerskappy gebring (Floor, 1983:28). Die doop in die Naam van die Vader beteken dat diegene wat die merk van die verbond of van die koninkryk ontvang het, onder God se vaderlike, koninklike sorg staan. Die doop in die Naam van die Seun, wat Here en Koning is, kan dus as 'n regeringsverandering omskryf word. Dit wat in die doop beteken en verseël word, bevry die dopeling van die slawerny van die sonde en die dood, en stel hom onder 'n nuwe Koning, waar hy vry is om 'n nuwe lewe te lei (Floor, 1983:29). Deur die doop in die Naam van die Heilige Gees word die dopeling onder die gesag, die regering van die Heilige Gees gebring. Die Gees is by magte om die hart van die dopeling te verander en te vernuwe.

Elkeen wat gedoop is, of hy dit aanvaar of nie, staan onder die gesag van die drie-enige God. Dit is onmiskenbaar in die doop bevestig. Om egter die nuwe gesag te erken, vra 'n radikale lewensverandering, 'n nuwe geboorte. Dit is die werk van die Heilige Gees.

In Handelinge en die briewe van die apostels word meestal van die "doop in die Naam van Jesus", of "doop in Jesus" gepraat. Handelinge 2:38 wil ook sê dat die doop in die Naam van Jesus Christus mag plaasvind, dit wil sê op basis van die openbaring van die 
persoon van Jesus, omdat die openbaring tot stand gekom het in die werk wat Hy volbring het (Versteeg, 1983:45). Die doop is nie op menslike bekering of berou gebaseer nie, maar alleen en uitsluitlik op die Naam van Jesus. Die beste wyse waarop die uitdrukking "in die Naam van Jesus" verstaan kan word, word deur Paulus in 1 Korintiërs 10:2 aangedui. Hy praat daar van die Israeliete wat "in Moses" gedoop is toe hulle na die uittog uit Egipte deur die Rooi See getrek het. ' $n$ Lokale verplasing van die Israeliete in Moses is nie hier ter sprake nie (Cross, 1999:185). Paulus bedoel dat die Israeliete met die tog deur die Rooi See gedoop is en daardeur aan Moses verbind is (Sparks, 2006:659). Die Israeliete was dus op Moses aangewese en het onder sy gesag gestaan. Die uitdrukking "doop in Christus" dui daarop om aan Christus verbind te wees deur die doop, sodat die gedoopte voortaan in elke opsig op Christus aangewese is en in alle opsigte onder die seggenskap (gesag) van Christus staan (Doriani, 2003:40).

Om gedoop te word, gaan ook nie net oor die verlossing en reiniging in Jesus en die aanvaarding van die Vader se beloftes nie. Dit dui ook op die begin én voortsetting van die werk van die Seun van God deur sy Gees. Die reinigende werk en die inwonende krag van die Heilige Gees word tematies in die doopformule in Matteus 28 aangedui (Pretorius, 2003:169).

The focus now falls on what has been achieved in the ministry of Jesus: he has fulfilled the role of Son of God and acted out of and made present the power of the Spirit of God. Though we find ourselves at a point of significant achievement, his work is not finished. He will be with those who will from now on act in His name. (Nolland, 1999:79.)

\section{6 "Leer hulle om alles te onderhou ..."}

Leer ( $\delta\llcorner\delta a ́ \sigma \kappa \omega$; vgl. Matt. 28:20) beteken volgens Louw en Nida (1996:33.224) om in 'n formele of informele opset, instruksie of onderrig te gee (vgl. Luk. 11:1). Die deelwoord is in die teenwoordige tyd en kan daarom met "terwyl julle die mense leer/deur mense te leer", vertaal word. Die aktiewe teenwoordige tyd dui ook op 'n volgehoue aksie. 'n Dissipel leer altyd ander en bly self ook leer (vgl.

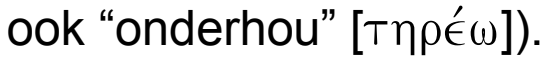

Jesus is die gesaghebbende Koning en subjek van die bevele (vgl. "Ek"). Hy onderrig self deur sy dissipels. "The only real teacher is Jesus himself. The church is basically a fellowship of his students." (Kvalbein, 1988:49.) Lering gaan dus met 'n persoonlike dissipel- 
skapsverhouding met Jesus gepaard, waarin liefde vir Hom die nodige onderskeiding gee (vgl. Fil. 1:10; Shore, 2006:325). Om te onderhou ( cause a state to continue - to cause to continue, to retain, to keep".

Die leerinhoud word as "alles wat Ek julle beveel het" aangedui. Samehangend met die vorige deel van die opdrag, word ook hier doel-

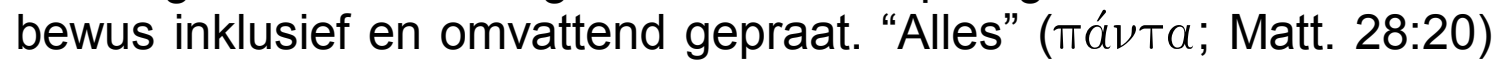
wat Jesus beveel het, moet geleer word (Pretorius, 2003:175).

\section{7 "En kyk, Ek is met julle ..."}

Jesus stuur hulle in sy krag uit wanneer Hy belowe "Ek is met julle". Dit is 'n geweldige belofte, want op drie sentrale plekke in Matteus kom dit voor. In die begin wanneer Hy as Immanuel, wat verlossing bring, aangedui word. Tweedens, wanneer oor die belangrike saak van kerklike dissipline gepraat word, stel Jesus dat Hy met hulle is om die integriteit van die kerk te red (Matt. 18:15-20; Krentz, 2006: 36; Shore, 2006:328); en derdens, waneer Hy belowe om by hulle te wees in hulle dissipelswees vir die nasies (Doriani, 2003:34).

\section{Prakties-teoretiese afleidings vir die doop}

- Die feit dat Jesus alle mag in die hemel en op aarde ontvang het, gee aan Hom die reg om die opdrag tot doop te gee.

- Die instelling van die doop, juis ná Jesus se opstanding en die ontvangs van alle mag, plaas die dopeling in die nuwe era van God se koninkryk.

- Die doop dien om Jesus se koningsheerlikheid te openbaar. Deur die doop laat Jesus as Koning sy regte oor die lewe van 'n gedoopte geld.

- Die dopeling word deur die doop aan die Persoon en wese van die drie-enige God verbind.

- In die lewe van die persoon wat gedoop word, vind 'n regeringsverandering plaas wat hom/haar onder die mag en heerskappy van Christus, die koninklike sorg van die Vader en die daaglikse regering van die Heilige Gees stel.

- Omdat Christus, as Here, absolute gesag het, kan Hy ook van die dopeling en doopouers onvoorwaardelike gehoorsaamheid eis. 
- Deur die doop laat Jesus sy seggenskap oor die lewe van die gedoopte en die doopouers geld, selfs al word dit nie deur hulle erken nie.

- Die gesag oor die dopeling en die doopouers word deur die prediking uitgeoefen, omdat Jesus sy gesag deur die prediking voortsit.

- Uit die doel waarom Jesus se prediking gesag het, kan afgelei word dat die gedoopte en die doopouers se lewensdoel die verheerliking van die Vader, Seun en Heilige Gees moet wees.

- Erkenning van die dopeling dat hy/sy deur die doop onder die gesag van Christus staan, vra van hom/haar 'n radikale en voortdurende lewensverandering.

- Die doop is op 'n lewe van bekering en vernuwing volgens die gebooie van Christus gerig.

- Die konteks waarin die opdrag tot doop gegee word, vereis dat die heerlikheid van Jesus as Koning deur die dopeling verkondig moet word.

- Die konteks waarin die doopopdrag gegee is, vereis ook van die dopeling en doopouers om met die uitdra van die evangelie grense oor te steek.

- Daar is 'n onlosmaaklike verband tussen "doop" en "onderhou wat Jesus geleer het", want God se gawe in die doop vra verdere toerusting.

- Die gedoopte is 'n dissipel wat geleer moet word, maar wat ook as dissipel ander moet leer.

- Die gedoopte leef onder die aangrypende en geweldige belofte dat Christus deur sy Gees altyd met hom/haar sal wees.

\section{Samevatting}

Die Vader het aan Jesus volmag vir sy werk op aarde gegee. Jesus het op grond van sy dood en opstanding alle mag in die hemel en op aarde ontvang en as Koning gee Hy die groot opdrag om dissipels te maak en hulle in die Naam van die Vader en die Seun en die Heilige Gees te doop. Sy gesaghebbende prediking dien dus as onderbou vir sy opdrag om die doop te bedien. 


\section{Geraadpleegde bronne}

ALLISON, D.C. 2004. Matthew: a shorter commentary based on the three volume International critical commentary. London: Clark.

BARRETT, C.K. 1970. The Gospel according to John: an introduction with commentary and notes on the Greek text. London: SPCK.

BAUCKHAM, R. \& MOSSER, C. 2008. The Gospel of John and Christian theology. Grand Rapids: Eerdmans.

BEASLEY-MURRAY, P. 1999. Baptism for the initiated. (In Porter, S.E. \& Cross, A.R., eds. Baptism, the New Testament and the church: historical and contemporary studies in honour of R.E.O. White. Journal for the study of the New Testament, Supplement series 171:467-476.)

BLIGHT, R.C. 2007. An exegetical summary of Luke 1-11. Dallas: Sil International.

BLOMBERG, C.L. 1992. Matthew: an exegetical and theological exposition of Holy Scripture. Nashville: Broadman \& Holman. (The New American Commentary.)

BORCHERT, G.L. 2002. John 12-21: an exegetical and theological exposition of Holy Scripture. Nashville: Broadman \& Holman. (The New American Commentary.)

BOSCH, D.J. 1995. The meaning of being a "disciple". Missio apostolica, 3(1):51-54.

BRODIE, T.L. 1993. The Gospel according to John: a literary and theological commentary. Oxford: Oxford University Press.

CAMPBELL, R.A. 1996. Jesus and his baptism. Tyndale bulletin, 47(2):191214.

CARTER, W. 2008. John and empire: initial explorations. London: Clark.

CROSS, A.R. 1999. "One baptism" (Ephesians 4:5): a challenge to the church. (In Porter, S.E, \& Cross, A.R., eds. Baptism, the New Testament and the church: historical and contemporary studies in honour of R.E.O. White. Journal for the study of the New Testament, Supplement series 171:173209.)

DAY, J.D. 2007. A fresh reading of Jesus' last words: Matthew 28:16-20. Review and expositor, 104(2):375-384.

DE KLERK, B.J. 1975. Die gesag van die prediking van Jesus. Potchefstroom: PU vir CHO. (Th.M.-verhandeling.)

DE KLERK, B.J. \& JANSE VAN RENSBURG, F.J. 2005. Making a sermon: a guide for reformed exegesis and preaching applied to 1 Peter 2:11-12, 1825. Potchefstroom: Potchefstroom Theological Publications.

DORIANI, D.M. 2003. Matthew 28:18-20 and the institution of baptism. (In Strawbridge, G. The case for covenantal infant baptism. Phillipsburg: P \& R. p. 30-48.)

EDWARDS, M. 2004. John. Oxford: Blackwell. (Blackwell Bible Commentaries.)

FLOOR, L. 1983. Die heilige doop in die Nuwe Testament. Potchefstroom: Potchefstroomse Teologiese Publikasies.

GEREFORMEERDE KERKE IN SUID-AFRIKA. 1970. Handelinge van die sewe-en-dertigste sinodale vergadering van die Gereformeerde Kerke in GKSA Suid-Afrika. Potchefstroom: Herald.

kyk GEREFORMEERDE KERKE IN SUID-AFRIKA 
GOLDINGAY, J. 2001. Isaiah: new international Biblical commentary. Peabody: Hendrickson.

GUNDRY, R.H. 1993. Mark: a commentary on his apology for the cross. Grand Rapids: Eerdmans.

HIEBERT, D.E. 1992. An expository study of Matthew 28:16-20. Bibliotheca sacra, 149(595):338-354.

KEENER, C.S. 1999. A commentary on the Gospel of Matthew. Grand Rapids: Eerdmans.

KRENTZ, E. 2004. Missionary Matthew: Matthew 28:16-20 as summary of the Gospel. Currents in theology and mission, 31(1):24-31.

KRENTZ, E. 2006. "Make disciples": Matthew on evangelism. Currents in theology and mission, 33(1):23-41.

KVALBEIN, H. 1988. Go therefore and make disciples: the concept of discipleship. Themelios, 13:48-53.

LOUW, J.P. \& NIDA, E.A. 1996. Greek-English Lexicon of the New Testament, based on semantic domains. Libronix digital library system 2001. [CDROM.]

LUCAS, E.C. 2002. Daniel. Leicester: Apollos. (Apollos Old Testament Commentary.)

MCDONNELL, K. 1995. Jesus' baptism in the Jordan. Theological studies, 56(2):209-236.

MITCHELL, N. 2009. Paul on baptism. Worship, 83(2):160-172.

MOLONEY, F.J. 1998. The Gospel of John. Collegeville: The Liturgical Press. (Sacra Pagina series.)

NEYREY, J.H. 2007. The Gospel of John. Cambridge: Cambridge University Press. (The New Cambridge Bible Commentary.)

NOLLAND, J. 1999. "In such a manner it is fitting for us to fulfil all righteousness": reflections on the place of baptism in the Gospel of Matthew. (In Porter, S.E. \& Cross, A.R., eds. Baptism, the New Testament and the church: historical and contemporary studies in honour of R.E.O. White. Journal for the study of the New Testament, Supplement series, 171:63-80.)

PENNINGTON, J.T. 2007. Heaven and earth in the Gospel of Matthew. Leiden: Brill.

PRETORIUS, J. 2003. Die groot fokus, die groot gebod en die groot opdrag as sleutels in 'n model vir gemeentebou. Potchefstroom: PU vir CHO. (Ph.D.proefskrif).

RIDDERBOS, H.N. 1987. Matthew: Bible student's commentary. Grand Rapids: Zondervan.

ROBERTSON, A.T. 1998. Word pictures in the New Testament. Libronix digital library system 2001. (Scholar's library.) [CD-ROM.]

ROSKAM, H.N. 2004. The purpose of the Gospel of Mark in its historical and social context. Leiden: Brill.

SHORE, M.H. 2006. Preaching mission: call and promise in Matthew 28:16-20. Word and world, 26(3):322-328.

SPARKS, K. 2006. Gospel as conquest: mosaic typology in Matthew 28:16-20. Catholic Biblical quarterly, 68(4):651-663.

STOTT, J.R.W. 1978. The message of the Sermon on the mount: the Bible speaks today. Leicester: InterVarsity.

VAN BRUGGEN, J. 1992. Marcus: het evangelie volgens Petrus. Kampen: Kok. (Commentaar op het Nieuwe Testament. Derde serie.) 
VAN SETTERS, J. 1994. The life of Moses: the Yahwist as historian in ExodusNumbers. Westminster: John Knox.

VERSTEEG, J.P. 1983. De doop volgens het Nieuwe Testament. (In Van 't Spyker, W., Balke, W., Exalto, K. \& Van Driel, L. Rondom de doopvont: leer en gebruik van de heilige doop in het Nieuwe Testament en in de geschiedenis van de westerse kerk. Kampen: De Groot Goudriaan. p. 9133.)

VOORBERG, P.L. 2007. Doop en kerk: de erkenning, door kerkelijke gemeenschappen, van de elders bediende doop. Heerenveen: Groen.

WADDELL, P. 2009. Ordained by Christ in his church: Jesus and baptism. Theology, 112(866):83-91.

WILSON, D. 2003. Baptism and children: their place in the Old and New Testament. (In Strawbridge, G. The case for covenantal infant baptism. Phillipsburg: P \& R. p. 286-302.)

WITHERINGTON III, B. 2001. The Gospel of Mark: a socio-retorical commentary. Grand Rapids: Eerdmans.

\section{Kernbegrippe:}

doop

gesag, prediking

Jesus

Matteus 28

Key concepts:

authority, preaching

baptism

Jesus

Matthew 28 